\title{
CIRCUMFERENTIAL INHOMOGENITY ANALYSIS IN G.A. SIWABESSY REACTOR'S PRIMARY COOLING PIPE
}

\author{
Roziq Himawan, Mike Susmikanti \\ PTKRN-BATAN, Gedung 80 Kawasan PUSPIPTEK, Serpong, Tangsel, 15310 \\ E-mail: roziqh@batan.go.id \\ Diterima editor: 1 April 2016 \\ Diperbaiki: 7 Oktober 2016 \\ Disetujui untuk publikasi: 13 oktober 2016
}

\begin{abstract}
CIRCUMFERENTIAL INHOMOGENITY ANALYSIS IN G.A. SIWABESSY REACTOR'S PRIMARY COOLING PIPE. In the in-service inspection conducted to G.A. Siwabessy reactor's primary cooling system pipe, it was found the presence of inhomogenity inside of welding part. To verify whether the inhomogenity could be tolerated or not, comparative data from welding pre-service inspection is needed. Unfortunately, this weld wasn't covered in pre-service inspection. Therefore, this inhomogenity needs to be analyzed. The purpose of this study is to evaluate the stress intensity factor of the inhomogenity, whether it is within a limit value or not and to predict the crack growth. Analysis were performed based on fracture mechanics theory using parameter of stress intensity factor. Two models were used for calculation approach that are plane crack model and semi-elliptic crack model. Hence, in order to predict the length of inhomogenity in the future, crack growth calculations were performed. The results showed that stress intensity values from both two models are remain below fracture toughness value of pipe's material. Besides that, stress intensity factor from plane crack model is higher than those from semi-elliptic crack model. Under consideration that inhomogenity has an arc shape in actual, thus, stress intensity factor from this inhomogenity still low enough compare to the fracture toughness. Crack growth calculation's results showed that after $300^{\text {th }}$ cycle of loading, the length of inhomogenity reaches approximately $2 \mathrm{~mm}$. Based on operation data of G.A. Siwabessy reactor, 300 cycle number is corresponds to 30 years operation. Based on these results it could be concluded that the presence of inhomogenity in the welding part does not affect the structure's integrity of piping system.
\end{abstract}

Keywords : Inhomogenity, fracture mechanics, fracture toughness, stress intensity factor, crack growth

\begin{abstract}
ABSTRAK
ANALISIS INHOMOGENITAS MELINGKAR PADA PIPA PENDINGIN PRIMER REAKTOR G.A. SIWABESSY. Pada pelaksanaan in-service inspection terhadap perpipaan sistem pendingin primer reaktor G.A. Siwabessy diketahui adanya inhomogenitas pada salah satu sambungan lasan pipa. Untuk memverifikasi apakah inhomogenitas ini dapat ditoleransi atau tidak, diperlukan data pembanding hasil pemeriksaan lasan pada saat fabrikasi. Namun, ternyata pada saat fabrikasi, sambungan lasan ini tidak mengalami pemeriksaan. Oleh karena itu, dalam rangka menetapkan apakah keberadaan inhomogentitas ini dapat ditoleransi atau tidak perlu dilakukan analisis terhadap inhomogenitas tersebut. Tujuan penelitian ini adalah untuk melakukan evaluasi stress intensity factor inhomogenitas di dalam pipa apakah masih berada di dalam batas nilai dan untuk memprediksi perambatan retak. Analisis dilakukan berdasarkan teori fracture mechanics dengan menghitung stress intensity factor inhomogenitas. Dalam perhitungan ini digunakan dua model untuk pendekatan, yaitu model retak planar dan model retak semiellips. Selanjutnya, untuk memprediksi panjang inhomogenitas di masa yang akan datang, dilakukan juga simulasi perambatan retak. Hasil-hasil analisis memperlihatkan bahwa nilai stress intensity factor berdasarkan model retak bentuk planar dan retak bentuk semi ellips masih jauh di bawah nilai fracture toughness material pipa. Selain itu, nilai yang dihasilkan berdasarkan model retak bentuk planar lebih besar dibandingkan dengan model retak bentuk semi ellips. Mengingat bentuk inhomogenitas yang berupa busur lingkaran, maka nilai stress intensity factor yang sesungguhnya dari inhomogenitas tersebut jauh lebih kecil dibandingkan dengan nilai fracture toughness. Sementara itu, untuk hasil simulasi perambatan retak menunjukkan bahwa pada siklus pembebanan ke-300 memberikan panjang sekitar 2 mm. Berdasarkan data operasi reaktor G.A. Siwabessy, jumlah siklus sebanyak 300 kali setara dengan pengoperasian reaktor selama 30 tahun. Berdasarkan dua hasil tersebut dapat disimpulkan bahwa keberadaan inhomogenitas pada sambungan lasan tidak berpengaruh terhadap integritas struktur sistem perpipaan.
\end{abstract}

Kata kunci : Inhomogenitas, fracture mechanincs, fracture toughness, stress intensity factor, pertumbuhan retak 


\section{INTRODUCTION}

Aging Management Program for a nuclear reactor facility aims to ensure the safe operation of the reactor. In accordance with the principle of management, one of the stages in the Aging Management Program is to acquire the actual condition of the aging process of a structure, systems, and components (SSCs) by performing testing or inspection to them. In general, inspection of the primary cooling system in reactor is important, especially inspection to it's piping systems. After the first criticality was achieved in 1987, G.A. Siwabessy Multi Purpose Reactor has been operated more than 25 years. In year 2014, the first in-service inspection of primary cooling system's pipe was performed for monitoring the condition of the pipe wall thinning and for checking the presence of crack in the weld joint. The results showed that there is no wall thinning in the pipe, but inhomogenity was found in one welding part [1]. This inhomogenity could not be determined as a defect, before carrying out an assessment to this inhomogenity. Assessment can be done by comparing with the pre-service inspection's results. Unfortunately, the weld part, where the inhomogenity was found, was not subjected to the pre-service inspection. Thus, comparison assessment could not be done. Therefore the assessment should be carried out by another method, to ensure the integrity of piping system.

Flexibility analysis of piping system of primary coolant in G.A. Siwabessy multipurpose reactor have been conducted in order to assess the piping design after long term operation. Analysis results showed that all values including force/load, bending moment and displacement occurs in the pipe is still below the allowed upper limit [2]. Thus, the load, bending moment and displacement on weld joints where inhomogenity located, also within allowed limit. It should be considered that upper limit in this case is for a condition that no presence of inhomogenity or crack. For pipe which has a crack, this criteria is not applicable. Therefore fracture mechanics analysis should be performed and fracture toughness should be the criteria. The purpose of this study is to evaluate the stress intensity factor of the inhomoginity, whether it is within a limit value or not and to predict the crack growth.

Fracture mechanics analysis of cracks in the pipe wall have been widely carried out intensively. Analysis were performed by assuming the crack geometry, crack orientation, crack position and load types subjected to the pipe. Planar circular cracks in the surface of the pipe has been analyzed by the axial tensile load, bending moment, a certain stress distribution, and stress at any direction [3-5]. Analysis of cracks in internal surface and outer surface pipe with semi-ellipticshaped have been carried out with the combination load that are axial tensile and bending loads, as well as loads due to pure torques [6-8]. Analysis on circular wall through cracks were analyzed both based on elastic theory and elastic plastic theory [9-11]. Analysis of pipe's cracks were also analyzed with the burden caused by the presence of residual stress $[12,13]$. Cracks in the surface of the pipe with axial orientation has been analyzed by the method of weight function [14]. Internal cracks on a solid cylindrical rod were analyzed in order to perform crack propagation analysis [15].

The in-service inspection's results of G.A. Siwabessy Multi Purpose Reactor gave an information that the position of inhomogenity was found in the primary cooling system pipe located at a depth of about $4 \mathrm{~mm}$ from the outer surface. Considering this condition, a fracture mechanics analysis of a defect embedded in the pipe's wall haven't been conducted. In this study, fracture mechanics analysis were performed using two approaches, i.e. a semi-elliptical cracks approach and planar surface crack approach. These two approaches can generate more moderate results than the actual conditions. After fracture mechanics analysis, stress intensity factors obtained from this calculation were used to calculate crack propagation rate prior to determining the remaining life of components. Thus, it can be used as a reference for determining repairing time of components containing cracks. 


\section{THEORY}

\section{Stress Intensity Factor Calculation}

As mentioned in the introduction, intensive studies have been performed regarding to stress field calculation of cracks in order to get stress intensity factor. In the implementation of in-service inspections of the primary coolant system's pipe of G.A. Siwabessy multi purpose reactor, inhomogenity was found in welding part. The inhomogenity has a circular (circumference) shape and the position is $4.5 \mathrm{~mm}$ from outer surface. Since the inhomogenity forms is an arc of a circle, fracture mechanics analysis were performed using two approaches in determining the shape. The first approach is using planar crack form in a pipe, while the second approach is using semielliptical cracks form on the internal surface. $1[16]$.

The first approach refers to fracture mechanics problem for planar cracks as shown in Figure

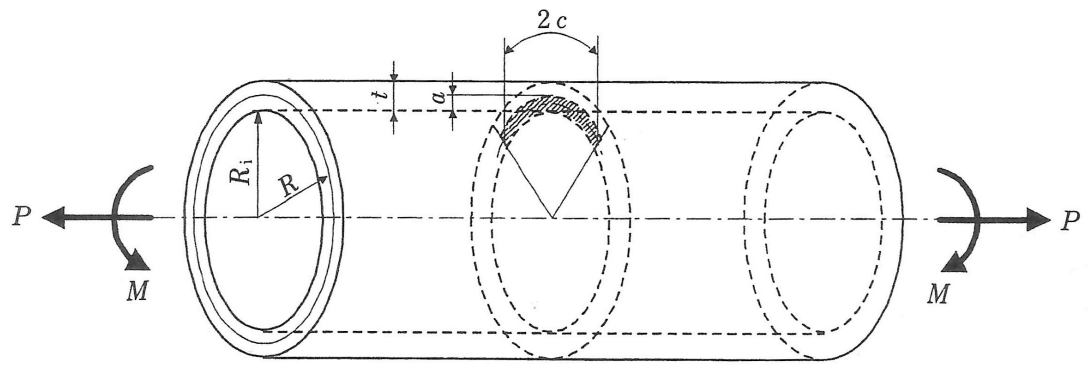

Figure 1. Circular planar crack model on internal surface [16].

Fracture mechanics analysis is conducted using parameter called Stress Intensity Factor (SIF). Calculation of SIF with crack configuration as illustrated in Figure 1, was based on the following equations [16]:

$$
\begin{aligned}
& K^{A}=\left(F_{m}^{A} \sigma_{m}+F_{b g}^{A} \sigma_{b g}\right) \sqrt{\pi a} \\
& \sigma_{m}=\frac{P}{2 \pi R t}, \quad \sigma_{b g}=\frac{M}{\pi R^{2} t} \\
& F_{m}^{A}=1.1+\frac{a}{t}\left[0.15241+16.722\left(\frac{a}{t} \frac{c}{\pi R_{i}}\right)^{0.855}-14.944 \frac{a}{t} \frac{c}{\pi R_{i}}\right] \\
& F_{b g}^{A}=1.1+\frac{a}{t}\left[-0.09967+5.0057\left(\frac{a}{t} \frac{c}{\pi R_{i}}\right)^{0.565}-2.8329 \frac{a}{t} \frac{c}{\pi R_{i}}\right]
\end{aligned}
$$

where $K^{A}$ is stress intensity factor, $F_{m}^{A}$ and $F_{b g}^{A}$ are shape factor, $\sigma_{m}$ and $\sigma_{b g}$ are stress due to tensile load and bending moment, $P$ is tensile load, $M$ is bending moment, $R$ is average diameter of inner and outer pipe diameter, $R_{i}$ is internal diameter of the pipe, $t$ is wall thickness, $a$ is a crack length in thickness direction, and $c$ is a crack length in circumferential direction. For $0.5<\frac{c}{\pi R_{i}}<1.0$ then $\frac{c}{\pi R_{i}}$ was calculated using value of 0.5 . The above equations are valid for stress intensity factor calculation under the following limitations $0.08 \leq \frac{a}{t} \leq 0.8 ; 0<\frac{a}{c} \leq 1$ and $0.05<\frac{c}{\pi R_{i}} \leq 1$. 
Superscript $A$ in $K^{A}$ indicates the stress intensity factor's value in the deepest point of crack. Subscript $m$ and $b g$ in $F$ and $\sigma$ indicate a portion due to tensile load and bending moment respectively.

As a second approach, the inhomogenity was assumed having semi-elliptic shape. Stress intensity factor calculations were performed based on fracture mechanic problems as ilustrated in Figure 2 [16].

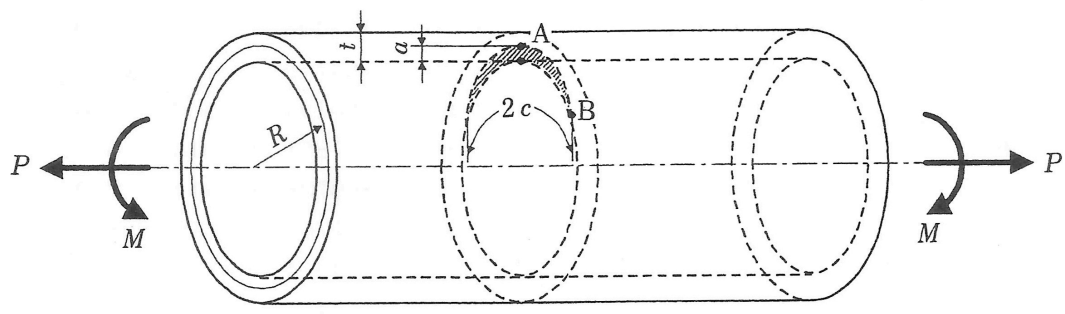

Figure 2. Semi elliptic crack model on internal surface [16].

and, stress intensity factor calculations were conducted base on the following equations [16].

$$
\begin{aligned}
& K^{A}=F_{m}^{A} \sigma_{m} \sqrt{\pi a}+F_{b g}^{A} \sigma_{b g} \sqrt{\pi t} \\
& \sigma_{m}=\frac{P}{2 \pi R t}, \quad \sigma_{b g}=\frac{M}{\pi R^{2} t} \\
& F_{m}^{A}=\left[1+\left\{0.02+0.0103 \alpha+0.00617 \alpha^{2}+0.0035(1+0.7 \alpha)(R / t-5)^{0.7}\right\} Q^{2}\right] / Q^{0.5} \\
& Q=1+1.464\left(\frac{a}{c}\right)^{1.65}
\end{aligned}
$$

Where $K^{A}$ is stress intensity factor, $F_{m}^{A}$ and $F_{b g}^{A}$ are shape factor, $\sigma_{m}$ and $\sigma_{b g}$ are stress due to tensile load and bending moment, $P$ is tensile load, $M$ is bending moment, $R$ is average diameter of inner and outer pipe diameter, $t$ is wall thickness, $a$ is a crack length in thickness direction, and $c$ is a crack length in circumferential direction. While $Q$ is a constant and $\alpha=2 c / t$. Superscript $A$ in $K^{A}$ indicates the stress intensity factor's value in the deepest point of crack. The stress intensity factor in point B is not considered, since stress intensity factor in point A has the biggest value. Subscript $m$ and $b g$ in $F$ and $\sigma$ indicate a portion due to tensile load and bending moment respectively. The values of $F_{b g}^{A}$ are shown in Table 1 . Table 1 was summarized from the references, which the contain choosen correspond with the geometrical conditions in this study.

Table 1. Value of $F_{b g}^{A}\left(\right.$ for $R_{i} / t=40$ ) [16].

\begin{tabular}{cccccc}
\hline $\mathbf{a} / \mathbf{t}$ & \multicolumn{5}{c}{$\mathbf{a} / \mathbf{c}$} \\
\cline { 2 - 6 } & $\mathbf{1 / 1 0}$ & $\mathbf{1 / 7}$ & $\mathbf{1 / 5}$ & $\mathbf{1 / 3}$ & $\mathbf{1} / 2$ \\
\hline 0.1 & 0.3720 & 0.3607 & 0.3473 & 0.3212 & 0.2955 \\
0.2 & 0.5288 & 0.5037 & 0.4844 & 0.4465 & 0.4158 \\
0.3 & 0.7091 & 0.6721 & 0.6328 & 0.5685 & 0.5174 \\
0.4 & 0.9157 & 0.8600 & 0.8010 & 0.7052 & 0.6300 \\
0.5 & 1.1486 & 1.0708 & 0.9889 & 0.8567 & 0.7536 \\
\hline
\end{tabular}




\section{Crack Growth Rate Calculation}

Crack growth rate calculation is an important aspect in order to determine the level of critical crack length. If one crack reaches a critical level, the cracks become unstable and go through the wall immediately. It means it reaches the life time. Crack growth rate calculations were conducted based on the following equation [16].

$$
d a / d N=C \Delta K^{n}
$$

where $\Delta K$ is the difference between minimum and maximum stress intensity factor during cyclic loading, $C$ and $n$ are a constant number. For austenitic stainless steel such as SUS $304, n$ is equal to 3.3 , while $C$, is categorized into three groups depend on stress ratio, $R$ (the ratio between maximum and minimum stress), that are [16]:

$$
\begin{aligned}
& R \leq 0 \text {, then } \quad C=10^{H} \times 18.61 \times 10^{-3} \\
& 0<R \leq 0.79 \text {, then } C=10^{H} \times 10^{-3} \times(18.61+33.5 R) \\
& 0.79<R<1 \text {, then } \quad C=10^{H} \times 10^{-3} \times(-806.85+1078.96 R)
\end{aligned}
$$

$\mathrm{H}$ value is defined according to the following equation [15].

$$
H=-9.984+1.337 \times 10^{-3} T_{c}-3.344 \times 10^{-6} T_{c}^{2}+5.949 \times 10^{-9} T_{c}^{3}
$$

in equation (10), if $R<1$ then $\Delta K$ value in equation (9) is substitued by $K_{\max } T_{c}$ in equation (13) is a temperature where the fatigue testing was conducted.

\section{METHODOLOGY}

The specification of the primary cooling system pipe with inhomogenity in the weld part is shown in Table 2. The inspection results showed that the inhomogenity has $10 \mathrm{~mm}$ in length [1]. The shape of inhomogenity is a circular arc line and $4.5 \mathrm{~mm}$ from the outer surface of the pipe. Thus, for calculating the stress intensity factor, as described in theory sub section, two approaches were applied. One is planar crack approach and the other one is semi-elliptical surface cracks. Illustration of these approaches are shown in Figure 3. Based on the illustration in Figure 3, crack length in circular direction has notation $2 c$ and the value is $10 \mathrm{~mm}$, while the thickness direction of the crack length, $a$, has a value of $1.8 \mathrm{~mm}$. The wall thickness of the pipe remains unchanged.

Table 2. Specification of primary cooling system's pipe [1].

\begin{tabular}{clc}
\hline No. & Item & Value \\
\hline 1 & Material & DIN 1.4541 \\
2 & Diameter (mm) & 609.9 \\
3 & Wall thickness (mm) & 6.3 \\
4 & Tensile strength (MPa) & $500-700$ \\
5 & Yield strength (MPa) & 240 \\
6 & Fracture toughness $\left(\right.$ MPa.m $\left.{ }^{1 / 2}\right)$ & $119-228$ \\
\hline
\end{tabular}



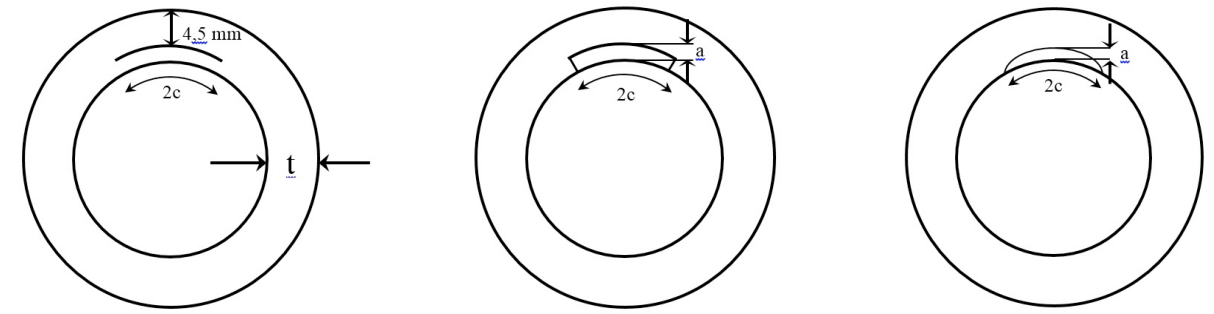

Figure 3. An embedded inhomogenity was assumed as planar crack and semi-elliptical crack [15].

According to the model shown in Figure 3, stress intensity factor calculations for planar crack and semi-elliptical crack were conducted. For these calculation, tensile loads and bending moments obtained from the analysis results of the pipe flexibility analysis shown in Table 3 were used [2].

Table 3. Load, bending moment and displacement values [2].

\begin{tabular}{lccccccccc}
\hline \multirow{2}{*}{ Load case } & \multicolumn{3}{c}{ Load [N] } & \multicolumn{3}{c}{ Bending moment [kg.m] } & \multicolumn{3}{c}{ Displacement [mm] } \\
\cline { 2 - 11 } & Fx & Fy & Fz & Mx & My & Mz & Dx & Dy & Dz \\
\hline Hydrostatic & 2 & 5 & 0 & 0 & 0 & 0 & 0.002 & 0.000 & 0.003 \\
Sustain & 5 & 7 & 0 & 0 & 0 & 0 & 0 & 0 & 0 \\
\hline
\end{tabular}

The results shown in this table were obtained under hydrostatic and sustain conditions, so that these results relatively have a significant values, compare to other conditions such as thermal stress, occasional load and expansion load. Hydrostatic is a condition which the load is generated by fluid flowing inside the pipe only, while the sustain condition is a condition which the load is generated by the weight of pipe and fluid flowing inside the pipe, the joint material, and support.

After calculating the stress intensity factor, crack propagation rate calculations were conducted using equation (1-8). Finally, simulations of crack propagation were conducted to determine the remaining life of the pipeline due to the presence of inhomogenity and the loads generated on the pipeline during operation. In remaining life assessment, number of loading cycles, $N$, were determined by refering to the number of start-up and shut-down of G.A. Siwabessy reactor in one year [17].

\section{RESULTS AND DISCUSSION}

Stress intensity factors calculation results are shown in Table 4. These results represented two calculations by using two load cases, i.e. hydrostatic and sustain conditions. However, for the load value, the highest value was taken, in this case, the load in the Y axis direction was choosen. This method was taken because of stress intensity factors calculation is determined only by load. According to Table 3, the value of bending moment for both conditions are zero. The results presented in this table represent two types of models, that are planar crack model and semi-elliptical crack models.

Table 4. Stress intensity factor (SIF) of inhomogenity $\left[\mathrm{MPa} . \mathrm{m}^{1 / 2}\right]$

\begin{tabular}{lcc}
\hline \multicolumn{1}{c}{ Load case } & Planar Crack Model & $\begin{array}{c}\text { Semi-elliptical crack } \\
\text { models }\end{array}$ \\
\hline Hydrostatic & 35.99 & 34.57 \\
Sustain & 50.39 & 48.39 \\
\hline
\end{tabular}

According to Table 4, it can be seen that stress intensity factor's values for planar crack models is slightly larger than semi-elliptical crack model. It applies for both sustain condition of hydrostatic 
and conditions. Greater value for this model of planar crack was caused by the crack geometry. For planar models, there are points of discontinuity that lead to stress concentration, while for semielliptical model there is no geometrical discontinuity, as consequence, no stress concentration in this crack model. Thus, the results obtained by planar cracks models provided more moderate value or safer side.

If the values of SIF in Table 4 are compared to the fracture toughness values in Table 2, the value of SIF is smaller than the value of fracture toughness. These two parameters are important for governing crack growth. As long as the stress intensity factor is smaller than fracture toughness, stable crack growth will take place. Contrarily, if stress intensity factor is beyond fracture toughness, unstable crack growth will take place which could lead to fracture. Therefore, according to this analysis results, if the inhomogenity is experiencing propagation, it will be a stable propagation. As shown in Figure 3, inhomogenity in the pipe is a circumference shape and not initiated from inner surface of the pipe, thus the SIF values obtained by the two models are large enough compared to the actual conditions. Therefore, both results are very moderate values.

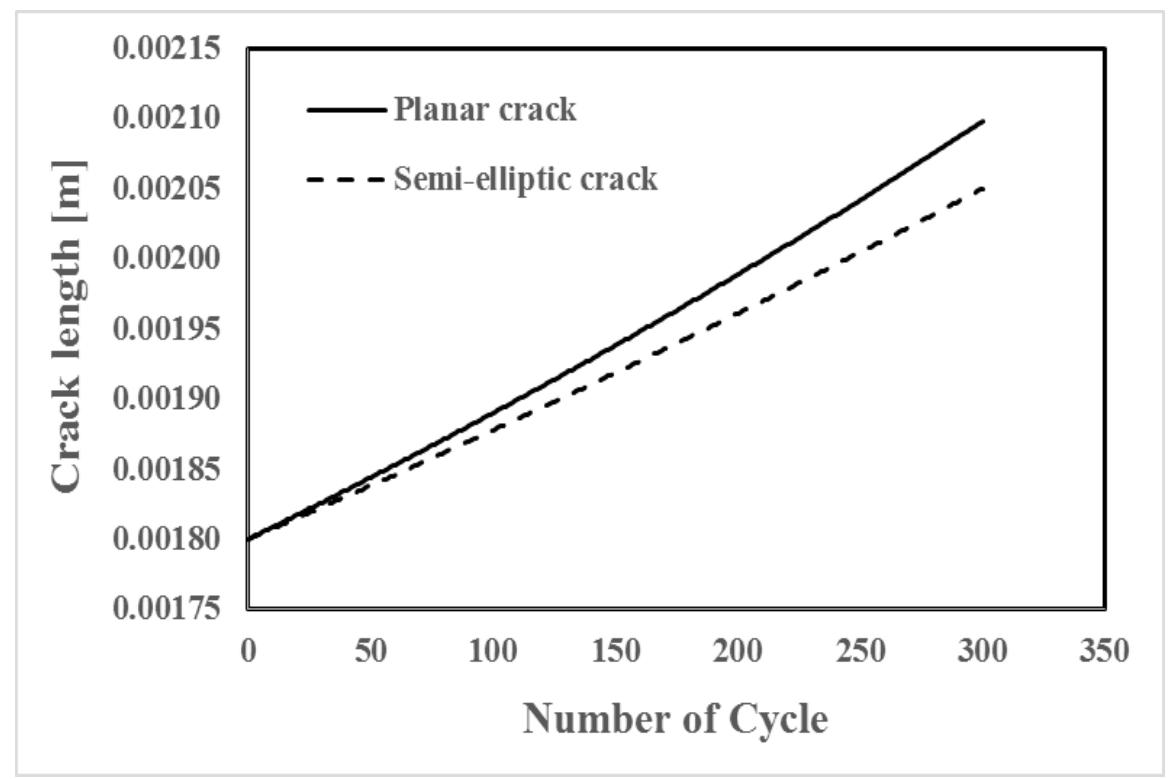

Figure 4. Relationship between number of cycle and crack length.

Figure 4 shows relationship between number of cycles and crack length, obtained from the result of crack length simulation based on the number of loading cycles. The simulations were conducted according to equation [9]. In this study, crack growth simulations were performed up to 300 loading cycles. According to the operation data of the reactor G.A. Siwabessy, there are 10 operations (ten times the start-up and shut-down ten times) in one year [17]. Thus, 300 numbers of loading cycles, it represents loading cycles for 30 years operation. Solid lines represents planar crack model, while the dash lines represents semi-elliptical crack model. In this graph, it can be known that the higher number of loading cycles that work, for both models shows the increase in crack length. If those two graphs are compared, it can be seen that for planar crack model resulted a greater final crack length than from semi-elliptical crack model. This is consistent with the calculation of SIF values as previously described. At the end of the cycle number, $\mathrm{N}=300$, a new crack length reaches about $2 \mathrm{~mm}$. If we consider that the pipe wall thickness is $6.3 \mathrm{~mm}$, the result is still about one third of the existing pipe thickness. However, when considering the actual inhomogenity which has arc-shaped, it can be predicted that during the operation for the next 30 years, inhomogenity still take place stable crack growth and there is no worry regarding to leakage of coolant water. 


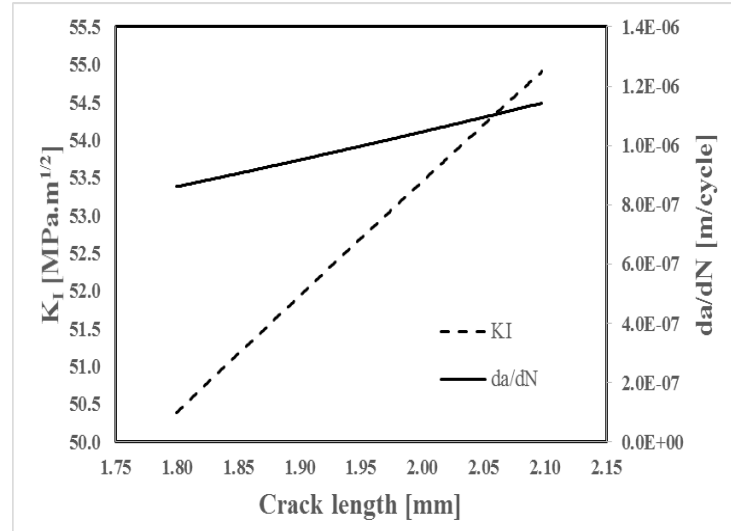

(a)Planar model

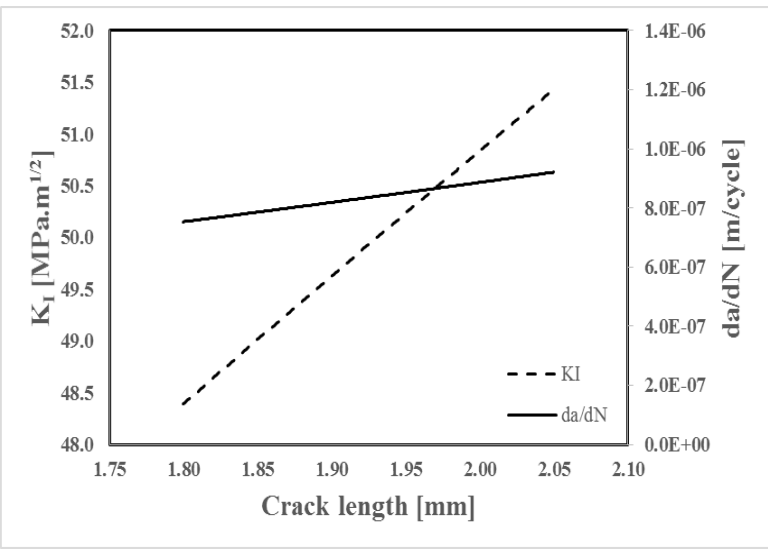

(b) Semi-elliptic model

Figure 5. Relationship between crack length, SIF values and crack growth rate.

Figure 5 shows the relationship between the crack length, SIF values and crack growth rate. Figure 5 (a) shows the results for planar crack models and 5 (b) shows the results for the semielliptical crack model. The second graph shows that the longer the length of the crack, the crack propagation rate, da/dN, and the value of the stress intensity factor increases. Both relationships and trend, are valid for both two models. Furthermore, when compared both results, the planar crack models provided greater results than the semi-elliptical crack model. It means a planar crack model provide a moderate value in calculation or simulation.

According to the calculations and simulations results obtained as described above, it is known that the presence of inhomogenity in the weld joint in the primary cooling system piping G.A. Siwabessy does not affect the structural integrity aspect. According to the crack propagation simulation result as shown in Figure 4 that the crack reaches $2 \mathrm{~mm}$ in length after 300 loading cycle and referring that 300 loading cycles represent 30 years operation, it could be considered that the reactor is still can be operated for the next 30 years with no probability of fracture. However, a periodic inspection should be taken in order to ensure the actual condition of inhomogenity. Especially, when abnormal loading occur to the piping system, such as a big earthquake, it could affect to the inhomogeneity propagation.

\section{CONCLUSION}

Fracture mechanics analysis and crack growth simulation have been carried out against inhomogenity in the weld joint in the reactor primary coolant system pipe G.A. Siwabessy. The simulations is to determine the level of integrity during the next 30 years. Analysis results and simulations showed that planar crack models provided greater results than the semi-elliptical crack 
models, for both the value of stress intensity factor and crack length. According to the results obtained, it can be concluded that the presence of inhomogenity does not affect the level of structural integrity of the piping system, even for operation for thirty years into the future. However, periodic inspection against the inhomogenity is needed to monitor its actual status.

\section{ACKNOWLEDGMENT}

Financial support for this study from Center for Nuclear Reactor Technology and Safety's Budget is gratefully acknowledged.

\section{REFERENCES}

1. Roziq Himawan dan Dwijo Mulyanto. Laporan Pengujian Lasan Perpipaan Sistem Pendingin Primer Reaktor Serbaguna G.A. Siwabessy: Pusat Reaktor Serba Guna, BATAN; Juni 2014. Report No.: 01/NDT-UTI/RSG/VI/2014.

2. Anonym. Piping Flexibility Analysis Report for Primary Cooling System: Pusat Reaktor Serba Guna, BATAN; Mei 2015. Report No.: PRSG-2004-CAL-1-R1.

3. NN, ASME Boiler and Pressure Vessel Code, Section XI Appendix C, Rules for In-service Inspection of Nuclear Power Plant Components, 2008.

4. Toshiyuki M., Katsuhiko W. Stress intensity factor for a circumferential crack in a finitelength thin to thick-walled cylinder under an arbitrary biquadratic stress distribution on the crack surfaces. Engineering Fracture Mechanics 2001; 68:975-986.

5. Iman E., Nasser S. Stress intensity factor calculation for internal circumferential cracks in functionally graded cylinders using the weight function approach. Engineering Fracture Mechanics 2015; 134:1-19.

6. Zahoor A. Closed form expressions for fracture mechanics analysis of cracked pipes. Trans. ASME, J. of Pressure Vessel Technology 1985; 107:203-209.

7. Ngoc H.D., Hedi S. Stress intensity factors and fatigue growth of a surface crack in a drill pipe during rotary drilling operation. Engineering Fracture Mechanics 2012; 96:626-640.

8. Predan J., Mocilnik V., Gubeljak N. Stress intensity factors for circumferential semielliptical surface cracks in a hollow cylinder subjected to pure torsion. Engineering Fracture Mechanics 2013; 105:152-168.

9. Joong-Hyok A., Yun-Jae K., Peter J.B. Elastic stress intensity factors and crack opening displacements for circumferential through-walled cracked elbows. Engineering Fracture Mechanics 2010; 77:2821-2839.

10. Chul-Goo K., Kyung-Dong B., Hyun-Suk N., Yun-Jae K. J estimation of circumferential through-wall intrados center cracked elbows under in-plane bending. Procedia Materials Science 2014; 3:886-893.

11. Chattopadhyay J., A.K.S. Tomar, B.K. Dutta, H.S. Kushwaha. Elastic-plastic J and COD estimation schemes for throughwall circumferentially cracked elbow under in-plane closing moment. Engineering Fracture Mechanics 2005; 72:2186-2217.

12. H.E. Coules., D.J. Smith. The maximum possible stress intensity factor for a crack in an unknown residual stress field. Int. J. of Pressure Vessel and Piping 2015; 134:33-45.

13. Chang-Young O., Yun-Jae K., Young-Jin O., Jong-Sung K., Tae-Kwang S., Yong-Beum K. Evaluation of stress intensity factors due to welding residual stresses for circumferential cracked pipes. Int. J. of Pressure Vessel and Piping 2013; 105-106:36-48.

14. Rahman S. Stress intensity factors for internal surface cracks in autofrettaged functionally graded thick cylinders using weight function method. Theoritical and Applied Fracture Mechanics 2015; 75:113-123.

15. R.P. Joseph, J. Purbolaksono, H.L. Liew, S. Ramesh, M. Hamdi. Stress intensity factors of a corner crack emanating from a pinhole of a solid cylinder. Engineering Fracture Mechanics $2014 ; 128: 1-7$. 
16. Hideo, KOBAYASHI, et al. Handbook: Assessment of Structural Integrity (printed in Japanese). Tokyo, Japan: Kyouritsu Publication; 2005.

17. NN. Schedule of Operation and Maintenance of RSG-GAS 2016. Rev. 2 (June 2016), Available from: URL: http://www.batan.go.id/index.php/id/fasilitas-prsg-2. Accessed June $29,2016$. 